\title{
First Record of Sericomyrmex mayri for Paraguay and Increasing the Range of Distribution of 17 Ant Species in the Central Department
}

\author{
Claus Brehm ${ }^{1} \&$ Victor Gómez ${ }^{2}$ \\ ${ }^{1}$ Peace Corps, Paraguay \\ ${ }^{2}$ Plant Protection Department, Faculty of Agrarian Sciences, National University of Asunción, San Lorenzo, \\ Paraguay \\ Correspondence: Victor Gómez, Plant Protection Department, Faculty of Agrarian Sciences, National University \\ of Asunción, Route II Mcal, Estigarribia Km 10.5, University Campus, San Lorenzo, Paraguay. E-mail: \\ victor.gomez@agr.una.py
}

Received: May 20, 2021

Accepted: June 20, $2021 \quad$ Online Published: July 15, 2021

doi:10.5539/jas.v13n8p84

URL: https://doi.org/10.5539/jas.v13n8p84

\begin{abstract}
Ants have been studied in Paraguay, South America, over the last two centuries, nevertheless new species can still be discovered with simple sample surveys. Most species collected in the country belong to one or few locations, therefore knowledge about species distribution is limited. A total of 2,040 ants have been collected, belonging to 7 subfamilies and representing 44 species. All of these species, except Sericomyrmex mayri, were documented for Paraguay and 17 species were first documented in the Central Department. Those 17 species are: Camponotus sanctaefidei, Crematogaster acuta, C. arata, Cyphomyrmex laevigatus, C. lectus, C. minutus, Forelius pusillus, Linepithema neotropicum, L. pulex, Mycetomoellerius fiebrigi, Nylanderia docilis, Pheidole cyrtostela, Pogonomyrmex tenuipubens, Solenopsis megergates, S.richteri, Strumigenys hindenburgi, and Wasmannia lutzi. These species belong to 12 genera and 3 subfamilies. The new recorded species is described and illustrated with photographs of the collected specimens as well as a short description of taxonomy, ecology, and distribution. A list of the new species to the Central Department is also provided. The aim of this study is to increase the knowledge of ant species in Paraguay and their distribution.
\end{abstract}

Keywords: ants, distribution, taxonomy

\section{Introduction}

Paraguay, South America, is divided into two broad regions by the Paraguay River: The Occidental Region and the Oriental Region. The Central Department is located in the middle of Paraguay with a range of ecosystems, from natural grasslands, gallery forests, flood plains along the Paraguay River to wetlands around the Ypacarai Lake (Avila et al., 2018). It is also the most populated place of the country, as the mayor cities are located within its limits. This means there is considerable pressure on the natural resources as demand for housing, water, energy and waste disposal is increasing. Birds and mammals are among the most studied components of the fauna, but arthropods, especially ants, have been less studied. Worldwide, 12,571 ant species are known to science, belonging to 22 subfamilies (Rabeling et al., 2008), with 3,100 ant species are cited in the Neotropics (Fernandez, 2003). Roughly a sixth of the Neotropic ants live in Paraguay with 541 described species (Wild, 2007a). Using the Chaos-2 statistical estimations, species richness ranges between $698 \pm 35$ species. Knowledge about ants still remains scattered and incomplete and Paraguay's ant fauna is among the most poorly studied in the Neotropics (Wild, 2007a). Most recent works done by Delsinne et al. $(2008,2010,2012)$ have recorded new species of ground dwelling ants for Paraguay. The aim of this study was to describe species of ants in the Central Department of Paraguay.

\section{Methods}

Field work was carried out between March 2019 and April 2019 in the locality of Cocue Guazú, Areguá, in the

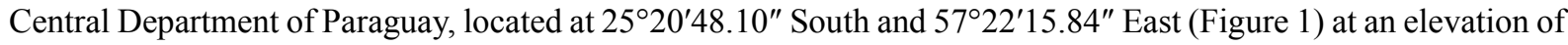
172 m.a.s.l. and belonging to the Ecoregion Litoral Central (Avila et al., 2018). 

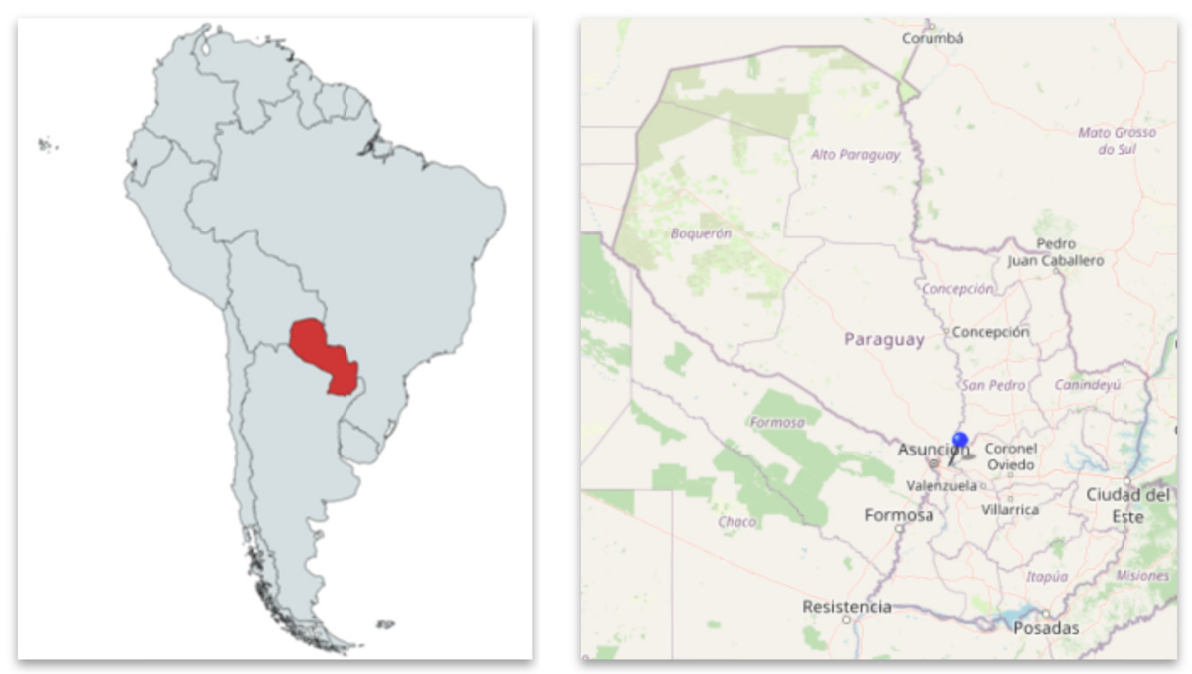

Figure 1. Location of the sample area

Three sample plots on a 50 meter transect were established and every 5 meters a pitfall was installed. The pitfall collection method was chosen as it is the most efficient trap for ground dwelling arthropods (Wiezik et al., 2015; Sheikh et al., 2018). Pitfalls were $7.5 \mathrm{~cm}$ in diameter on the top and $12 \mathrm{~cm}$ in height. They were filled with a $50 \%$ diluted alcohol solution. Traps were collected and reinstalled once a week. The contents were then stored in $80 \%$ diluted alcohol in labeled containers. After 4 weeks of collection the resulting 120 containers were filtered and only ant specimens were retained. The ant specimens were identified to genus using morphological keys from Bolton $(1994,1995,2019)$ and Baccaro et al. (2015). To identify to species, a catalogue was created based on the species list published for Paraguay by Wild (2007a), and the taxonomic keyy by Fernandez et al. (2003). The collected ant specimens were stored in the Collection of the Facultad de Ciencias Exactas y Naturales (FACEN) of the Universidad Nacional de Asunción (UNA). Measurements and pictures were taken with a BOECO BSZ-450 Stereoscope and a B-Cam 14 Camera. Parameters measured were Total Length (TL), Head Width (HW), Scape Length (SL), Weber's Length (WL), Petiole Length (PL), Hind Femur Length (HFL), Cephalic Index (CI) = $(\mathrm{HW} / \mathrm{HL}) \times 100$ and Scape Index $(\mathrm{SI})=(\mathrm{SL} / \mathrm{HW}) \times 100$. A total of 9 queens and workers of S.mayri were measured and their average values calculated.

\section{Results and Discussion}

The genus Sericomyrmex belongs to the higher Attini group which are fungus farming ants such as Atta and Acromyrmex (Ješovnik \& Schultz, 2017) which have an important role in nutrient cycling in the ecosystem. Higher Attini means that the ants are polymorphic, presenting certain degree of variation among individuals of the same colony. They provide their fungal gardens with fresh vegetal material, therefore ant species belonging to this group are of special interest to agricultural and forest plantations. Even though the genus Sericomyrmex was first described by Mayr (1865), it was not until 2017 that a full set of taxonomic keys and a clear species description was available (Ješovnik \& Schultz, 2017). The previous authors described 11 species and 3 subspecies from Mexico to southern Brazil. Sericomyrmex lives in a variety of habitats, such as deserts, savannah, forests, and urban areas (Mehdiabadi \& Schultz, 2010).

In Paraguay, the only documentation of this genus was Sericomyrmex scrobifer collected in the Department of Canindeyú by Alexander Wild in 2002 (Ješovnik \& Schultz, 2017).

S. mayri has been reported in northern Bolivia, Colombia, Ecuador, Peru, the Guianas, and throughout Brazil (Figure 2, Ješovnik \& Schultz, 2017). The specimens collected in Paraguay therefore represent the southernmost location of this species. 


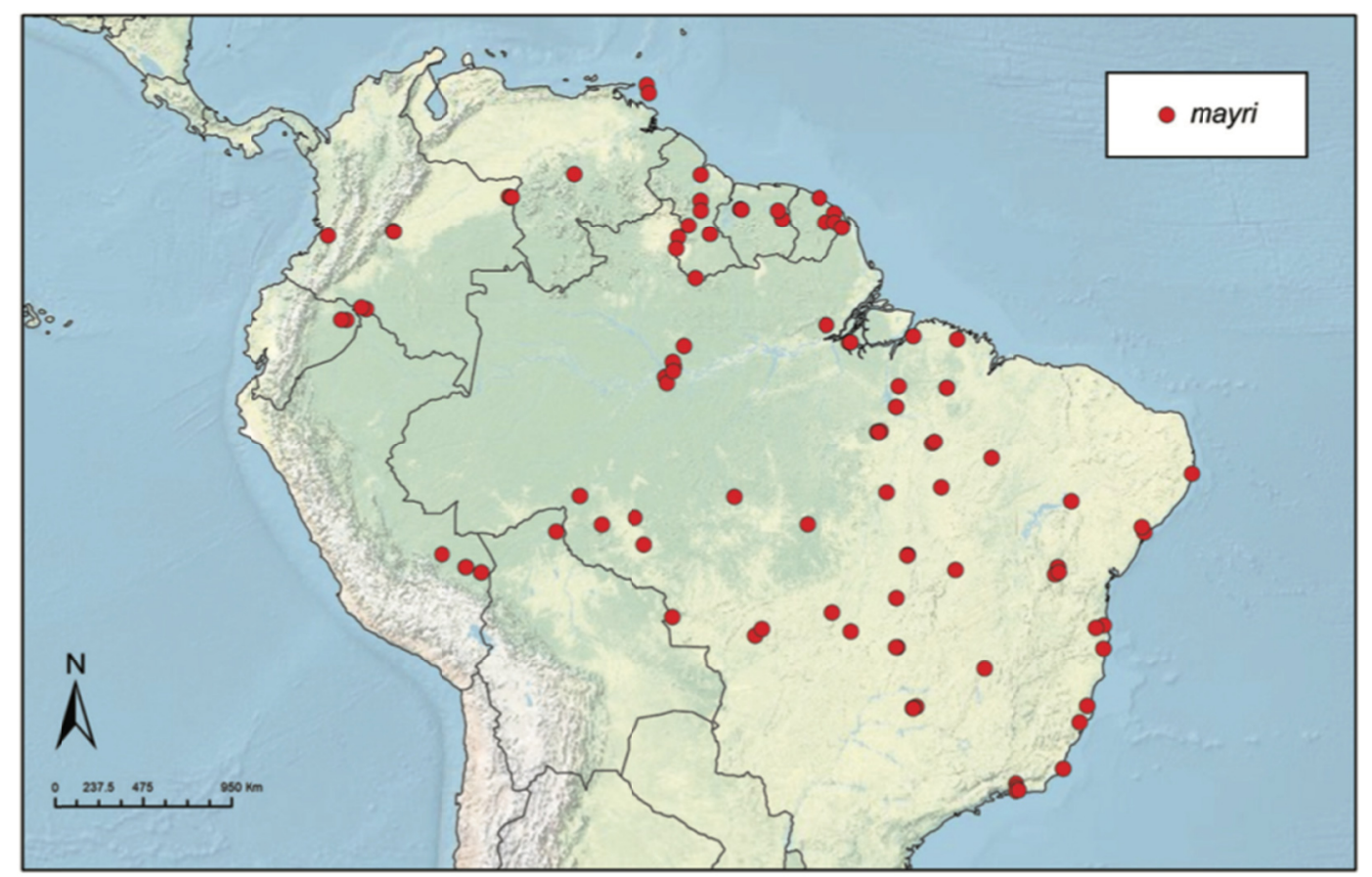

Figure 2. Known distribution of S.mayri (Ješovnik \& Schultz, 2017)

As only one species of this genus has been documented for Paraguay, this study may prompt the discovery of larger ant species.

The other 17 species first recorded for the Central Department belong to 12 genera and 3 subfamilies. Despite this study's short period of sampling, numerous species were recorded for the first time in this part of Paraguay. Table 1 shows where ant species have been recorded previously and by whom. Recommended for future Paraguay ant study is more samplings in different ecoregions of the country, and molecular biology analysis. Additionally, future research should include country-wide ant species distribution, ecology, and the impact of land use and climate change on species composition.

\subsection{Taxonomy}

\section{(1) Sericomyrmex mayri (Forel, 1912)}

Species description from Ješovnik and Schultz (2017): Large species; head broad; frontal lobe narrow, directed anterad; mandible usually striate; frontal carina often reduced, incomplete; eye flat to mildly convex; posterior cephalic margin shallow, abruptly to gradually impressed; posterior cephalic corner usually angled; mesosomal tubercles low and obtuse, first gastral tergite with lateral carina well developed, dorsal carinae absent or faint. Body covered with hair, which gives a silky appearance to the ant. This is where the name Sericomyrmex is derived from as Latin "sericeus" means "silky".

\section{(2) Worker Description}

Measurements in mm, range: TL 6.25-7.88 (7.11), HW 1.81-2.56 (2.12), HL 1.63-2.32 (1.93), SL 1.39-1.95 (1.60), WL 2.26-3.24 (2.76), PL 0.54-0.76 (0.64), HFL 2.07-3.03 (2.51), CI 104-115 (110), SI 70-81 (75) [N = 50]. Head: Wider than long $(\mathrm{CI}=110 \pm 5)$. Mandibles with 7-8 teeth and striated laterally. Eye slightly convex, medium-sized. Antennal scape short $(\mathrm{SI}=75 \pm 5)$. Pilosity: Body, head and legs covered with dense flexuous pubescence. Hairs curved, darker at the base, white to yellow. Mesosoma: Propodeal carinae flat, mesosomal tubercles not pronounced. Metasoma: Petiole and post petiole both with a longitudinal serrated carinae (Figure $3)$.

\subsection{Ecology}

S. mayri is difficult to observe in their natural habitat, as they move slowly and their color camouflages them. When these ants are disturbed, they stop moving unlike running to their nests like other ground-dwelling ant species. The plot where all the $S$. mayri specimens were collected had a continuous forest cover, constituted mainly 
of Kupa'i (Copaifera langsdorfii), Kurupa'y kurú (Anadenanthera colubrina), Tataré (Chloroleucon tortum), Yvyra ro (Pterogyne nitens) and a few specimens of Mbokaya palm trees (Acrocomia aculeata).

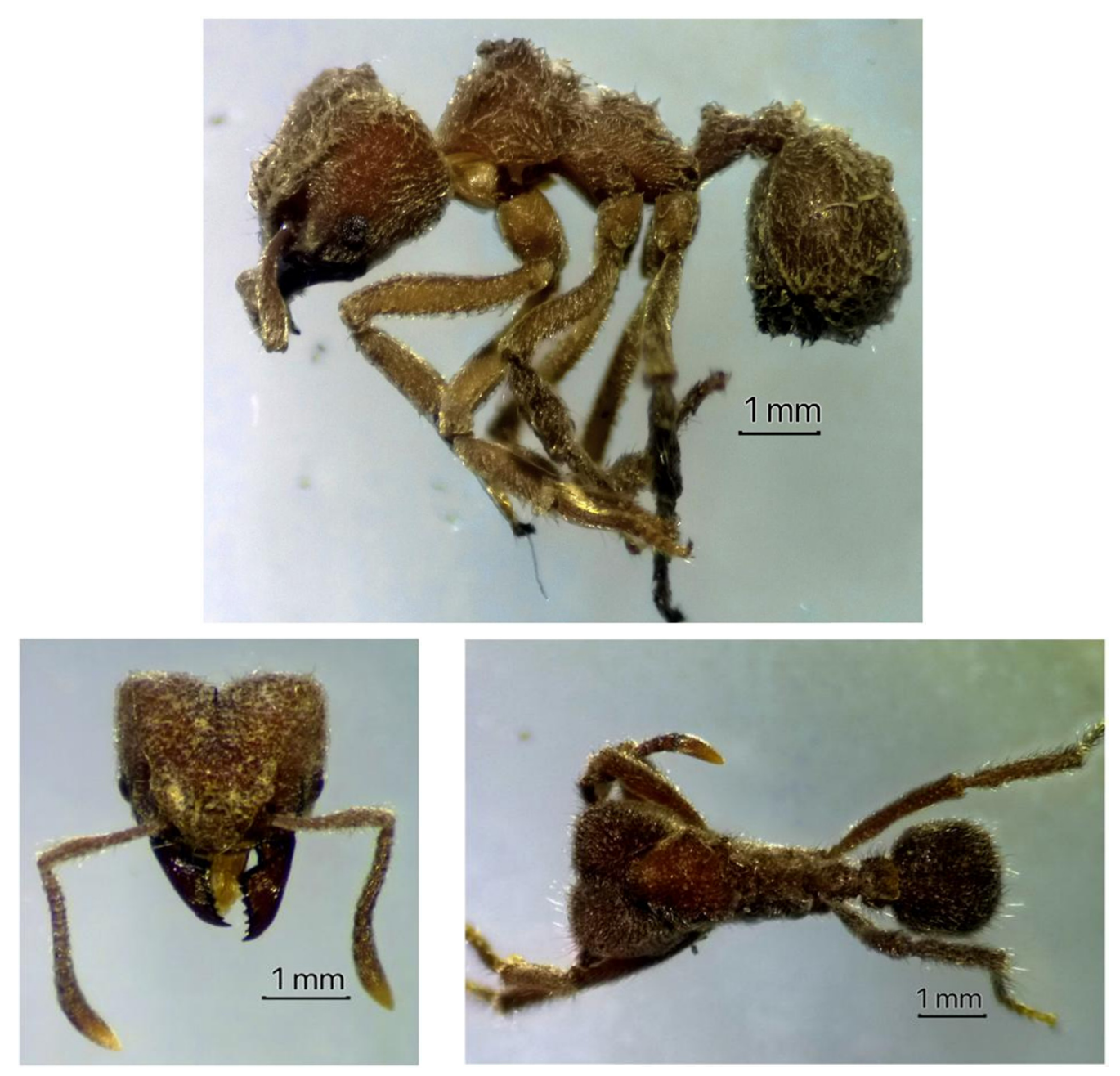

Figure 3. Sericomyrmex mayri worker 


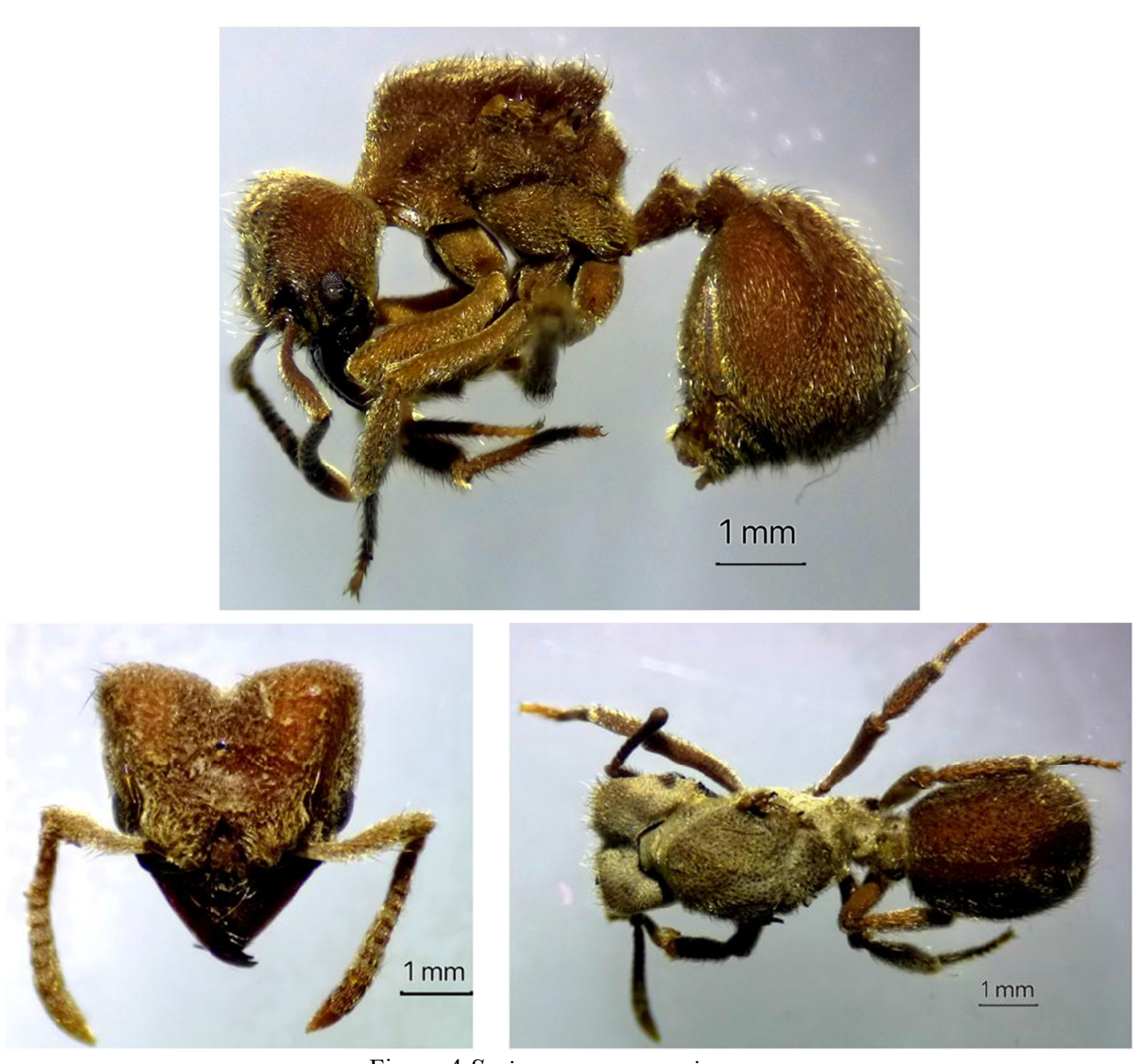

Figure 4 Sericomyrmex mayri queen

(1) S. mayri Queen Description

Measurements in mm, range: TL 8.05-9.13 (8.89) HW 3.05-3.17 (3.1) HL 2.88-2.98 (2.93) SL 2.25-2.69 (2.53) WL 3.85-4.02 (3.94) PL 0.91-0.96 (0.94) HFL 3.02-3.22 (3.12) CI 102-108 (106) SI 74-84 (82) [N = 8] (Figure 4). 
Table 1. New species recorded for the Central Department of Paraguay

\begin{tabular}{|c|c|c|c|c|}
\hline & Subfamily & Species & Distribution in Paraguay & References \\
\hline 1 & \multirow{3}{*}{ Dolichoderinae } & Forelius pusillus (Santschi) & $\mathrm{CA}$ & Wild, 2007a \\
\hline 2 & & Linepithema neotropicum (Wild) & $\mathrm{CA}, \mathrm{AP}$ & Wild, 2007b \\
\hline 3 & & Linepithema pulex (Wild) & $\mathrm{CA}$ & Wild, 2007b \\
\hline 4 & \multirow{2}{*}{ Formicinae } & Camponotus sanctaefidei (Dalla Torre) & $\mathrm{CG}, \mathrm{CA}, \mathrm{N} E, \mathrm{SP}$ & Wild, $2007 \mathrm{a}$ \\
\hline 5 & & Nylanderia docilis (Forel, Brandão) & $\mathrm{CA}$ & Wild, 2007a \\
\hline 6 & \multirow{12}{*}{ Myrmicinae } & Crematogaster acuta (Fabricius) & $\mathrm{CA}$ & Wild, $2007 \mathrm{a}$ \\
\hline 7 & & Crematogaster arata (Emery) & $\mathrm{CA}, \mathrm{GU}, \mathrm{MI}$ & Wild, 2007a \\
\hline 8 & & Cyphomyrmex laevigatus (Weber) & $\mathrm{CA}$ & Wild, 2007a \\
\hline 9 & & Cyphomyrmex lectus (Forel) & $\mathrm{CO}$ & Wild, 2007a \\
\hline 10 & & Cyphomyrmex minutus (Mayr) & CA, MI & Wild, 2007a \\
\hline 11 & & Mycetomoellerius fiebrigi (Santschi) & 1916-Santschi no location mentioned & Santschi, 1916 \\
\hline 12 & & Pheidole cyrtostela (Wilson) & $\mathrm{AM}$ & Wilson, 2003 \\
\hline 13 & & Pogonomyrmex tenuipubens (Santschi) & CG & Fowler, 1981; Taber, 1998 \\
\hline 14 & & Solenopsis megergates (Trager) & $\mathrm{BO}$ & Trager, 1991 \\
\hline 15 & & Solenopsis richteri (Forel) & $\tilde{\mathrm{N}} \mathrm{E}$ & Fowler, 1981 \\
\hline 16 & & Strumigenys hindenburgi (Forel) & IT & Fowler, 1981 \\
\hline 17 & & Wasmannia lutzi (Forel) & IT & Forel, 1908 \\
\hline
\end{tabular}

Note. Names of the Paraguayan Departments are abbreviated as follows: AP: Alto Paraguay; AR: Alto Paraná; AM: Amambay; BO: Boquerón; CG: Caaguazú; CZ: Caazapá; CA: Canindeyú; CE: Central; CO: Concepción; CR: Cordillera; GU: Guairá; IT: Itapúa; MI: Misiones; ÑE: Ñeembucú; PR: Paraguarí; PH: Presidente Hayes; SP: San Pedro.

\section{Conclusion}

A total of 2,040 ants were collected in this study, belonging to 7 subfamilies and representing 44 species. All of these species, except Sericomyrmex mayri have previously been documented in Paraguay, though this study is the first to document all 17 species in the Central Department of Paraguay. These results suggest that ant diversity in Paraguay is largely underestimated. Future studies concerning this important arthropod group may uncover additional information regarding ranges of known species and locating heretofore unknown species nationally.

\section{References}

Avila, I., D’Elia, G., Vogt, C., \& Garcete-Barrett, B. (2018). Analisis crítico de la Biogeografia del Paraguay. Reportes Cientificos de FACEN, 9(1), 42-50. https://doi.org/10.18004/rcfacen.2018.9.1.42

Baccaro, F. B., Feitosa, R. M., Fernandez, F., Fernandes, I. O., Izzo, T. J., Souza, J. L. P., \& Solar, R. (2015). Guia para os gêneros de formigas do Brasil. INPA, Manaus.

Bolton, B. (1994). Identification Guide to the Ant Genera of the World. Harvard University Press, USA.

Bolton, B. (1995). A New General Catalogue of the Ants of the World. Harvard University Press, USA.

Bolton, B. (2019). An online catalog of the ants of the world. Retrieved from http://antcat.org

Delsinne, T., Leponce, M., Theunis, L., Braet, Y., \& Roisin, Y. (2008). Rainfall Influences Ant Sampling in Dry Forests. Biotropica, 40(5), 590-596. https://doi.org/10.1111/j.1744-7429.2008.00414.x

Delsinne, T., Leponce, M., Theunis, L., Mackay, W. P., \& Roisin, Y. (2012). Distribution and Diversity of the Cryptic Ant Genus Oxyepoecus (Hymenoptera: Formicidae: Myrmicinae) in Paraguay with Descriptions of Two New Species. Psyche: A Journal of Entomology, 2012, Article ID 594302. https://doi.org/10.1155/ 2012/594302

Delsinne, T., Roisin, Y., Herbauts, J., \& Leponce, M. (2010). Ant diversity along a wide rainfall gradient in the Paraguayan dry Chaco. Journal of Arid Environments, 74, 1149-1155. https://doi.org/10.1016/j.jaridenv. 2010.03.014

Fernandez, F. (2003). Introducción a las Hormigas de la región Neotropical (Vol. XXVI, p. 398). Instituto de Investigación de Recursos Biológicos Alexander von Humboldt, Bogotá, Colombia. 
Forel, A. (1908). Ameisen aus Sao Paulo (Brasilien), Paraguay etc. gesammelt von Prof. Herm. v. Ihering, Dr. Lutz, Dr. Fiebrig, etc. Verhandlungen der Kaiserlich-Königlichen Zoologisch-Botanischen Gesellschaft in Wien, 58, 340-418.

Forel, A. (1912). Formicides néotropiques (Part I). Annales de la Société Entomologique de Belgique, 56, $28-49$.

Fowler, H. G. (1981). Nuevos registros de hormigas para el Paraguay (Hymenoptera Formicidae). Neotropica (La Plata), 26, 183-186.

Ješovnik, A., \& Schultz, T. R. (2017). Revision of the fungus-farming ant genus Sericomyrmex Mayr (Hymenoptera, Formicidae, Myrmicinae). ZooKeys, 670, 1-109. https://doi.org/10.3897/zookeys.670.11839

Mayr, G. (1865). Formicidae. Reise der Österreichischen Fregatte "Novara" um die Erde in den Jahren 1857, 1858, 1859 unter den Befehlen des Commodore B. von $W$ (Novara Expedition 1865, p. 119). Wien, Kaiserlich-K1861-75.

Mehdiabadi, N. J., \& Schultz, T. R. (2010). Natural history and phylogeny of the fungus-farming ants (Hymenoptera: Formicidae: Myrmicinae: Attini). Myrmecological News, 13, 37-55.

Rabeling, C., Brown, J. M., \& Verhaagh, M. (2008). Newly discovered sister lineage sheds light on early ant evolution. PNAS, 105(39), 14913. https://doi.org/10.1073/pnas.0806187105

Santschi, F. (1916). Formicides sudaméricains nouveaux ou peu connus. Physis (Buenos Aires), 2, 365-399.

Sheikh, A., Ganaie, G., Thomas, M., Bhandari, R., \& Rather, Y. (2018). Ant pittfall trap sampling: An Overview. Journal of Entomological Research, 42(3), 421-436. https://doi.org/10.5958/0974-4576.2018.00072.5

Taber, S. W. (1998). The World of the Harvester Ants (p. 213). College Station: Texas A\&M University Press.

Trager, J. C. (1991). A revision of the fire ants, Solenopsis geminata group (Hymenoptera: Formicidae: Myrmicinae). Journal of the New York Entomological Society, 99, 141-198.

Wiezik, M., Svitok, M., Wieziková, A., \& Dovčiak, M. (2015). Identifying Shifts in Leaf-Litter Ant Assemblages (Hymenoptera: Formicidae) across Ecosystem Boundaries Using Multiple Sampling Methods. PLoS ONE, 10(7), e0134502. https://doi.org/10.1371/journal.pone.0134502

Wild, A. L. (2007a). A catalogue of the ants of Paraguay (Hymenoptera: Formicidae). Zootaxa, 1622, 1-55. https://doi.org/10.11646/zootaxa.1622.1.1

Wild, A. L. (2007b). Taxonomic revision of the ant genus Linepithema (Hymenoptera: Formicidae). University of California Publications in Entomology, 126, 1-159.

Wilson, E. O. (2003). Pheidole in the New World. A dominant, hyperdiverse ant genus (p. 794). Cambridge, Massachusetts, Harvard University Press.

\section{Copyrights}

Copyright for this article is retained by the author(s), with first publication rights granted to the journal.

This is an open-access article distributed under the terms and conditions of the Creative Commons Attribution license (http://creativecommons.org/licenses/by/4.0/). 